\title{
Diagnosis dan Tatalaksana Terkini Gagal Jantung Akut
}

\author{
Lifi Saroinsong, ${ }^{1}$ Edmond L. Jim, ${ }^{2}$ Starry H. Rampengan ${ }^{2}$
}

\author{
${ }^{1}$ Program Studi Pendidikan Dokter Fakultas Kedokteran Universitas Sam Ratulangi, Manado, \\ Sulawesi Utara, Indonesia \\ ${ }^{2}$ Bagian Ilmu Penyakit Jantung dan Pembuluh Darah Fakultas Kedokteran Universitas Sam \\ Ratulangi, Manado, Sulawesi Utara, Indonesia \\ Email:lifisaroinsong@gmail.com
}

\begin{abstract}
Acute heart failure (AHF) is an emergency condition with rapid onset that requires immediate treatment. Many factors play a role in the incidence of AHF thus providing various of clinical manifestation. Prevalence and mortality of AHF is still a major health problem in Asia with the highest prevalence rate. This study intended to determine the tests needed to establish a diagnosis and recent treatment needed for AHF. This was a literature review study. The results showed the development of diagnosis and management of AHF based on the class of recommendation and levels of evidence updated by ESC 2016 and ACC/AHA/HFSA 2017. Furthermore, 4 journals discussed the development of troponin as biomarkers, multiple biomarkers, miRNA, and Lung Ultrasound (LUS). The development in AHF management was using tolvaptan, serelaxin, and neuromuscular electrical stimulation (NMES). In conclusion, diagnosis through anamnesis, physical examination, and supporting AHF can be done by understanding the causes of fluid retention and decreased cardiac output of the patient, therefore, it can provide pharmacological and non-pharmacological treatment appropriately.
\end{abstract}

Keywords: diagnosis, treatment, acute heart failure

\begin{abstract}
Abstrak: Gagal jantung akut (GJA) merupakan kondisi darurat dengan tipe serangan yang cepat sehingga membutuhkan penanganan segera. Banyak faktor yang berperan dalam kejadian GJA sehingga memberikan gambaran klinis yang beragam. Prevalensi dan mortalitas GJA di dunia terus mengalami peningkatan dan masih merupakan masalah kesehatan utama di Asia. Penelitian ini bertujuan untuk mengetahui pemeriksaan yang diperlukan untuk menegakkan diagnosis GJA dan perkembangan tatalaksana terkini GJA. Jenis penelitian ialah literature review. Hasil penelitian mendapatkan perkembangan diagnosis dan tatalaksana GJA berdasarkan kelas rekomendasi dan tingkatan bukti yang diperbaharui oleh ESC 2016 dan ACC/AHA/HFSA 2017. Selain itu, 4 jurnal membahas perkembangan penggunaan biomarker troponin, biomarker multipel, miRNA, serta USG Paru. Perkembangan tatalaksana GJA menggunakan tolvaptan, serelaksin, dan neuromuscular electrical stimulation (NMES). Simpulan penelitian ini ialah penegakan diagnosis lewat anamnesis, pemeriksaan fisik dan penunjang GJA dapat dilakukan dengan memahami penyebab retensi cairan dan penurunan curah jantung pasien sehingga dapat memberikan tatalaksana farmakologis dan non-farmakologis dengan tepat.
\end{abstract}

Kata kunci: diagnosis, tatalaksana, gagal jantung akut

\section{PENDAHULUAN}

Kejadian gagal jantung akut (GJA) di dunia berdasarkan data European Society of Cardiology (ESC) menunjukkan bahwa sebanyak $65-75 \%$ dari 186,364 pasien tersebut mempunyai riwayat gagal jantung dengan rerata usia berkisar 70-73 tahun. Data ini dikumpulkan dari Amerika Serikat, Meksiko, Australia, Turki, Sub-Sahara Afrika dan berbagai negara yang sudah tergabung dalam Benua Eropa. ${ }^{1,2}$ Selain itu, GJA masih menjadi masalah kesehatan mayor di 
Asia dengan prevalensi gagal jantung yaitu Thailand (19\%), Vietnam (15\%), Filipina (9\%) dan Taiwan $(2,2 \%))^{3,4}$ Angka prevalensi Malaysia sebesar 6,7\% dan Singapura sebesar 4,5\% merupakan prevalensi tertinggi di Asia bahkan di dunia. ${ }^{5}$ Pada tahun 2018, Riset Kesehatan Dasar (Riskesdas) mencatat bahwa prevalensi penyakit jantung mencapai angka 1,5\% dengan umur diatas 15 tahun. ${ }^{6}$

Sebuah studi kohort yang dilakukan oleh Dokainish et $\mathrm{al}^{7}$ mencatat bahwa dari 16 negara yang tercatat dalam penelitian tersebut, Asia Tenggara menempati posisi ketiga setelah Afrika dan India sebagai daerah dengan angka mortalitas gagal jantung tertinggi. Negara-negara di Asia dengan angka mortalitas tinggi pada pasien yang dirawat adalah Korea Selatan dan Thailand yaitu sebesar 6\%. Persentase ini terbilang tinggi dibandingkan negara lain di Asia. Pada tahun 2016 Reyes et al $^{3}$ menunjukkan bahwa Indonesia memiliki angka mortalitas pasien gagal jantung sebesar $17 \%{ }^{3}$

Gagal jantung akut digambarkan sebagai kondisi darurat yang memerlukan penanganan yang segera karena tipe serangan yang cepat ini membutuhkan diagnosis dan terapi yang segera karena dapat mengancam nyawa. Terdapat banyak faktor yang berperan dalam kejadian GJA seperti disfungsi miokardium akut karena iskemia, inflamasi, penggunaan obat-obatan, gangguan nutrisi, penyakit endokrin, atau toksin. Penyebab lain juga berasal dari perburukan gagal jantung yang ditandai dengan dekompensasi dikarenakan kurangnya edukasi mengenai pengobatan, aritmia, infeksi, anemia, dan lainnya. Banyaknya klasifkasi yang digunakan dapat membantu dalam menilai tingkat resiko komplikasi dan dapat membantu dalam memberikan terapi yang tepat pada pasien dalam kondisi darurat. ${ }^{6,7}$

Pemeriksaan lebih lanjut yang perlu dilakukan untuk mengonfirmasi kondisi pasien dapat dibantu dengan elektrokardiografi (EKG), foto toraks, ekokardiografi, kateterisasi jantung, serta pemeriksaan biomarker B-type natriuretic peptides (BNP) dan $N$-terminal pro hormone B-type natriuretic peptides (NT-pro BNP). Pemeriksaan ini dapat membantu mengkonfirmasi penyebab gagal jantung akut baik yang bersifat kardiak maupun non-kardiak. , $^{6-11}$ Setelah memahami kondisi pasien dengan pemeriksaan yang dilakukan, maka dapat diberikan terapi yang tepat sesuai dengan kondisi pasien, terapi yang dilakukan untuk GJA terbagi atas farmakologis dan nonfarmakologis. Terapi farmakologis yang digunakan untuk GJA yaitu golongan diuretik, penyekat enzim konversi angiotensin (EKA), vasodilator, vasopressor, dan inotropik. Selain itu, terapi non-farmakologis yang digunakan idalah terapi oksigen, transplantasi jantung, left ventricular assist device (LVAD), dan implantable cardiac defibrillator (ICD). ${ }^{6,7,12-14}$

Berdasarkan tingginya prevalensi dan mortalitas yang disebabkan oleh GJA, maka perlu dilakukan ulasan mendalam mengenai diagnosis dan tatalaksana terkini gagal jantung akut untuk mengetahui pemeriksaan yang diperlukan untuk menegakkan diagnosis GJA dan perkembangan tatalaksana terkini GJA.

\section{METODE PENELITIAN}

Jenis penelitian yang dilakukan ialah literature review untuk memberikan pengenalan mengenai penelitian, teori atau kajian baru sehingga dapat menambah informasi dan ilmu mengenai topik terkait. Selain itu, penelitian ini dapat membantu dalam menentukan teori, metode dan formulasi masalah penelitian yang dilakukan. ${ }^{15}$

Pencarian data yang memenuhi kajian literatur dan sesuai dengan topik dilakukan secara di luar jaringan (offline) dan di dalam jaringan (online). Pencarian yang dilakukan secara offline didapatkan dari berbagai buku-buku, sedangkan pencarian secara online dilakukan lewat situs jurnal ilmiah memiliki database yang beragam dan berkualitas.

Jumlah literatur yang dikumpulkan dari berbagai database yang berkaitan dengan topik yaitu, Clinical Key sebanyak 274 artikel, Pubmed sebanyak 359 artikel, dan Science Direct sebanyak 542 artikel. Selain itu, literature yang mendukung topik dapat ditemukan lewat database organisasi atau perhimpunan yang giat dalam bidang yang 
berkaitan dengan topik dalam hal ini organisasi atau perhimpunan yang bergerak di Bagian Jantung dan Pembuluh Darah. Literatur yang dikumpulkan berjumlah 18 artikel yang berasal dari American Heart Journal (AHJ) dan 24 artikel didapatkan dari ESC.

Keyword dan booleam operator (AND OR, NOT or AND NOT) digunakan untuk mencari artikel yang berhubungan dengan topik yang dipilih sehingga mempermudah dalam pecarian artikel yang akan dikaji. Kata kunci harus disesuaikan dengan topik yang akan dibahas di literature review. Diagnose OR Diagnosis AND Therapy OR Treatment $O R$ Management AND Acute Heart Failure OR Acute Decompensated Heart Failure OR Hospitalization Heart Failure OR Acute Heart Failure Syndrome AND Recent.

Kriteria inklusi dan eksklusi yang digunakan berdasarkan strategi Population, Intervention, Comparison, Outcomes, dan Study (PICOS). Populasi yang dipakai ialah pasien dengan GJA tanpa intervensi dan perbandingan. Desain penelitian dalam artikel yang digunakan ialah randomized controlled trial (RCT) yang dipublikasi pada 5 tahun terakhir (2015-2020) dan menggunakan Bahasa Indonesia dan Bahasa Inggris.
Jumlah keseluruhan artikel yang dikumpulkan ialah 1,263, selanjutnya dilakukan proses skrining sehingga didapatkan 160 artikel $(n=160)$. Jumlah artikel diperkecil setelah membaca bagian abstrak dan judul secara singkat dan total akhir menjadi 28 artikel $(n=28)$. Langkah terakhir idalah melakukan analisis full text dari 28 artikel tersebut dan didapatkan 18 artikel yang dikeluarkan karena topiknya yang tidak relevan dengan judul penelitian, sehingga didapatkan 10 artikel full text dalam final literature review.

\section{HASIL PENELITIAN}

Pada penelitian ini didapatkan 10 literatur yang berkaitan dengan diagnosis dan tatalaksana terkini gagal jantung akut. Terdapat 4 artikel yang membahas mengenai perkembangan diagnosis pada pasien dengan GJA dan 6 lainnya membahas mengenai perkembangan terapi untuk pasien yang mengalami GJA. Tabel 1 memperlihatkan distribusi judul, lokasi, dan desain penelitian yang digunakan dalam literatur mengenai perkembangan diagnosis.

Tabel 2 memperlihatkan distribusi judul, lokasi, dan desain penelitian dari literatur - literatur mengenai perkembangan tatalaksana GJA serta perkembangan terapi farmakologi dan non-farmakologis GJA.

Tabel 1. Distribusi judul, lokasi, dan desain penelitian masing-masing literatur mengenai perkembangan diagnosis GJA dengan desain penelitian RCT

\begin{tabular}{clcc}
\hline \multicolumn{1}{c}{ Peneliti } & \multicolumn{1}{c}{ Judul Penelitian } & Lokasi \\
\hline Pivetta et al, 201916 & $\begin{array}{l}\text { Lung ultrasound integrated with clinical } \\
\text { assessment for diagnosis of acute decompensated } \\
\text { heart failure in the emergency department: a } \\
\text { randomized controlled trial } \\
\text { Felker et al, 2015 }\end{array}$ & $\begin{array}{l}\text { Serial high sensitive cardiac troponin T } \\
\text { measurement in acute heart failure: insights from } \\
\text { the RELAX-AHF study }\end{array}$ & Inggris \\
Demissei et al, 2016 & $\begin{array}{l}\text { Optimizing clinical use of biomarker in high-risk } \\
\text { acute heart failure patients }\end{array}$ & Inggris \\
Vegter et al, 2016 ${ }^{19}$ & $\begin{array}{l}\text { Use of biomarker to esbalisih potential role and } \\
\text { functioning of circulation microRNAs in acute } \\
\text { heart failure }\end{array}$ & \\
& & & \\
\end{tabular}


Tabel 2. Distribusi judul, lokasi, dan desain penelitian masing-masing literatur mengenai perkembangan tatalaksana GJA dengan desain penelitian RCT

\begin{tabular}{|c|c|c|}
\hline Peneliti & Judul Penelitian & Lokasi \\
\hline $\begin{array}{l}\text { Shanmugam et al, } \\
2016^{20}\end{array}$ & $\begin{array}{l}\text { Effect of tolvaptan on acute heart failure with hyponatremia } \\
- \text { A randomized, double blind, controlled clinical trial }\end{array}$ & India \\
\hline $\begin{array}{l}\text { Konstam et al, } \\
2017^{21}\end{array}$ & $\begin{array}{l}\text { Short-term effects of tolvaptan in patients with acute heart } \\
\text { failure and volume overload }\end{array}$ & $\begin{array}{c}\text { Amerika } \\
\text { Serikat }\end{array}$ \\
\hline $\begin{array}{l}\text { Teerlink et al, } \\
2013^{22}\end{array}$ & Effects of serelaxin in patients with acute heart failure & 35 negara \\
\hline $\begin{array}{l}\text { Maggioni et al, } \\
2019^{23}\end{array}$ & $\begin{array}{l}\text { Efficacy and safety of serelaxin when added to standard of } \\
\text { care in patients with acute heart failure: results from a } \\
\text { PROBE study, RELAX-AHF-EU }\end{array}$ & 26 negara \\
\hline $\begin{array}{l}\text { Kondo et al, } \\
2019^{24}\end{array}$ & $\begin{array}{l}\text { Neuromuscular electrical stimulation is feasible in patients } \\
\text { with acute heart failure }\end{array}$ & Jepang \\
\hline
\end{tabular}

\section{BAHASAN}

\section{Diagnosis Terkini Gagal Jantung Akut}

Perkembangan diagnosis GJA terus mengalami perkembangan dengan kelas rekomendasi dan tingkatan bukti yang terus berubah. Perkembangan diagnosis GJA saat ini diambil dari pedoman ESC 2016 dan ACC/AHA/HFSA 2017. ${ }^{6,11}$

Pemeriksaan fisik seperti menilai derajat perfusi dan kongesti pada pasien masih direkomendasikan karena membantu dalam memberikan terapi awal yang tepat bagi pasien. Selain itu inspeksi jugular venous pressure (JVP), auskultasi untuk mendeteksi sistolik murmur, irama gallop, stenosis, ronki basah, dan konstriksi bronkial masih diperlukan untuk menilai kondisi pasien dan membantu dalam memahami penyakit yang mendasari kondisi pasien. ${ }^{6,11}$

Pemeriksaan penunjang yang direkomendasikan diberikan tingkatan atau kelas rekomendasi dan tingkatan bukti. Rontgen toraks dengan kelas rekomendasi I (memiliki bukti dan persetujuan bersama bahwa prosedur dan terapi yang diberikan bermanfaat dan efektif) dengan tingkatan bukti $\mathrm{C}$ (kumpulan pendapat ahli atau studi kecil dan retrospektif) pada ESC dan ACC/AHA/HFSA. Selanjutnya, EKG memiliki kelas rekomendasi I dan tingkatan bukti $\mathrm{C}$ karena dapat membantu dalam mendeteksi penyakit jantung yang mendasari kondisi pasien seperti fibrilasi atrium dan iskemik miokard akut. Pemeriksaan ekokardiografi menurut ESC dan ACC/AHA/HFSA memiliki kelas rekomendasi I dan tingkatan bukti C. ${ }^{6,11}$

Penggunaan biomarker BNP dan NTproBNP serta rontgen toraks merupakan pemeriksaan penunjang yang direkomendasikan oleh pedoman diagnosis dan tatalaksana GJA ESC 2016 dan ACC/AHA/HFSA 2017. ${ }^{6,11}$ Selanjutnya, pemeriksaan ini dilakukan uji oleh Pivetta et $\mathrm{al}^{16}$ dan dilakukan perbandingan dengan penggunaan evaluasi klinis dan pencitraan USG paru. Setelah dilakukan uji sensitifitas dan spesifisitas, didapatkan bahwa evaluasi klinis menggunakan pendekatan rontgen toraks dan NT-proBNP tidak menunjukkan perbedaan yang besar $(p>0,05)$, tetapi, jika dikombinasikan antara evaluasi klinis dan USG paru maka didapatkan nilai yang bermakna ( $p<0,01$ sensitifitas dan $p<0,05$ untuk spesifisitas).

Pemeriksaan biomarker lainnya seperti kardiak troponin dapat membantu dalam mendeteksi sindrom koroner akut sebagai salah satu penyakit yang dapat mendasari kejadian GJA. Pada pedoman ESC 2016, pemeriksaan kardiak troponin memiliki kelas rekomendasi I dengan tingkatan bukti C sedangkan pada ACC/AHA/HFSA 2017 pemeriksaan kardiak troponin memiliki kelas rekomendasi I dengan tingkatan bukti A sebagai nilai prognostik. ${ }^{6,11}$

Penelitian terbaru mengenai troponin lebih khusus mengenai high sensitivity cardiac troponin (hs-cTnT) sebagai biomarker pada GJA menunjukkan bahwa peningkatan kejadian dispnea berhubungan 
dengan peningkatan hs-cTnT dan memiliki hubungan yang kuat antara baseline hscTnT dengan gagal jantung $(\mathrm{p}<0,0001) .{ }^{17}$

Pedoman ESC 2016 menunjukkan bahwa pemeriksaan biomarker multipel dapat dipertimbagkan sebagai pemeriksaan pada pasien GJA. Deteksi inflamasi dan stres oksidatif dapat dilakukan dengan pemeriksaan biomarker multipel dan telah dilakukan investigasi lebih lanjut mengenai nilai diagnostik dan prognostik yang berhubungan dengan gagal jantung. ${ }^{6}$ Pernyataan dalam ESC 2016 ini sejalan dengan penelitian oleh Demissei et al ${ }^{18}$ mengenai peran pemeriksaan biomarker multipel yang menunjukkan bahwa nilai prognostik yang lebih baik setelah dilakukan evaluasi cardiac troponin-1 (cTn1) bersama blood urea nitrogen (BUN), klorida, interleukin-6 (IL6), soluble suppression of tumorigenicity-2 (sST-2), dan vascular endhothelial growth factor receptor-1 (VEGFR-1) dengan CIndex $0,8495 \%$ CI $[0,77-0,90]$ untuk semua penyebab mortalitas 30 hari. $^{18}$

Perkembangan biomarker sebagai pemeriksaan yang membantu dalam memahami kondisi pasien dibahas oleh Vegter et al. ${ }^{19}$ Pada penelitian ini Vegter et al membahas mengenai peran dan fungsi dari miRNA dalam sirkulasi dengan kejadian GJA dan didapatkan beberapa korelasi negatif yang bermakna antara biomarker dan miRNA yang berhubungan dengan waktu pengukuran, tingkat keparahan penyakit, perburukan klinis, perburukan fungsi ginjal, kebutuhan terapi, dan perburukan gejala dispnea pada 24 atau 48 jam dengan perburukan keadaan pasien (Tabel 3). ${ }^{19}$

Tabel 3. Korelasi antara biomarker dengan biomarker miRNA pada penyakit gagal jantung akut $^{19}$

\begin{tabular}{ll}
\hline Biomarker & Biomarker miRNA \\
\hline CRP & miR-16-5p \\
Galectin-3 & miR-199a-3p \\
sST-2 & miR-652-3p \\
Kreatinin & miR-106a-5p \\
PCT & miR-199a-3p dan \\
& miR-18a-5p \\
GDF-15 & miR-223-3p \\
\hline
\end{tabular}

Tatalaksana Terkini Gagal Jantung Akut

Perkembangan tatalaksana GJA berdasarkan pedoman ESC 2016 dan ACC/ AHA/HFSA 2017. Terapi farmakologis seperti penggunaan loop diuretic dan penyekat EKA masih direkomendasikan menurut pedoman ESC 2016 dan ACC/ AHA/HFSA 2017. Kelas rekomendasi I dan tingkatan bukti $\mathrm{C}$ untuk diuretik dan Kelas rekomendasi I dan tingkatan bukti A untuk penyekat EKA. Kedua terapi ini dapat digunakan untuk mengurangi tanda dan gejala kelebihan cairan serta dapat membantu menurunkan mortalitas dan morbiditas pada pasien dengan gajala gagal jantung ringan, sedang, berat dengan atau tanpa sindrom koroner akut. ${ }^{6,11}$

Penelitian terbaru mengenai penggunaan tolvaptan yang dapat menstimulasi penurunan volume cairan dalam tubuh dengan cara menginhibisi reabsorpsi air yang dimediasi oleh vasopressin pada ginjal, menyebabkan ekskresi air meningkat tanpa memberiksan efek penurunan natrium. ${ }^{25-27}$ Pemberian tolvaptan lebih awal dapat memberikan efek penurunan berat badan dan perbaikan sesak napas. Namun dari ketiga penelitian yang dilakukan ulasan, tidak didapatkan perbedaan bermakna antara kelompok plasebo dan tolvaptan jika diberikan dalam jangka panjang. ${ }^{20,21,28}$

Penggunaan inotropik pada pasien gagal jantung memiliki kelas rekomendasi I dan tingkatan bukti C pada ACC/AHA/ HFSA 2017. Penggunaan inotropik bermanfaat pada pasien GJA dengan syok kardiogenik agar dapat mempertahankan perfusi sistemik. ${ }^{6,11}$

Pemberian vasodilator direkomendasikan dengan kelas rekomendasi IIb dan tingkatan bukti C. Tekanan darah sistolik $<90 \mathrm{mmHg}$ pada pasien tidak dianjurkan untuk menerima vasodilator karena dapat menurunkan perfusi organ sentral sehingga meningkatkan mortalitas. ${ }^{6}$ Penelitian mengenai jenis baru golongan vasodilator yaitu serelaksin. Serelaksin merupakan obat yang terbuat dari human relaxin-2 yang dikembangkan sebagai obat yang memiliki potensi sebagai vasodilator dengan sifat proteksi terhadap organ. ${ }^{29}$ 
Hasil penelitian RELAX-AHF-2 menunjukkan bahwa pemberian serelaksin 0,5 jam setelah inisiasi loop diuretic selama 5,3 jam tidak memberikan perbedaan signifikan $(8,7 \%)$ dengan kelompok plasebo $(8,9 \%)$. Selain itu, hasil kedua titik akhir penelitian menunjukkan pemberian serelaksin tidak menyebabkan penurunan insiden mortalitas yang disebabkan penyakit kardiovaskular pada 180 hari dan perburukan gagal jantung dalam 5 hari. $^{22}$

Pemberian serelaksin yang dikombinasikan dengan perawatan standar memberikan perbedaan bermakna antara kelompok serelaksin dan plasebo yang berhubungan dengan perburukan gagal jantung atau kematian dengan semua penyebab selama 5 hari. Studi RELAX-AHF-EU meneliti efek serelaksin dengan menggunakan protokol yang sama dengan RELAX-AHF-2. Namun, perlu diperhatikan bahwa pengunaan serelaksin yang dimasukkan dalam perawatan standar hanya dapat dilakukan pada populasi dengan karakteristik pasien GJA yang mirip dengan penelitian ini sehingga tidak dapat digeneralisasikan pada semua populasi pasien dengan GJA. ${ }^{23}$

Perkembangan terapi non-farmakologis pada pasien GJA mengalami perkembangan berdasarkan rekomendasi ESC 2016 dan ACC/AHA/HFSA 2017. Penggunaan ultrafiltrasi dan transplantasi ginjal dengan kelas rekomendasi IIb dan tingkatan bukti B. Pasien dengan kondisi terminal gagal jantung dianjurkan untuk menggunakan LVAD yang dapat membantu mempertahankan kondisi pasien yang akan menerima transplantasi jantung dengan kelas rekomendasi IIa dan tingkatan bukti C. ICD juga direkomendasikan pada pasien dengan aritmia ventrikel dan status hemodinamik yang tidak stabil. ICD digunakan untuk menurunkan resiko mortalitas dengan kelas rekomendasi I dan tingkatan bukti A. ${ }^{6,11}$

Penelitian mengenai terapi non-farmakologi lainnya dan dapat digolongkan sebagai terapi terbaru ialah penggunaan Neuromuscular Electrical Stimulation (NMES). Penggunaan NMES dapat mempertahankan massa otot pada pasien GJA dengan efek yang sama jika melakukan olahraga tipe aerobik. NMES dapat membantuk menginduksi kontraksi otot pada pasien GJA dengan kendala melakukan olahraga karena kemampuan hemodinamik dan respirasi yang menurun. ${ }^{24}$

\section{SIMPULAN}

Diagnosis terkini GJA dapat dilakukan dengan memahami penyebab retensi cairan dan penurunan curah jantung pada pasien melalui anamnesis tanda dan gejala, pemeriksaan fisik derajat perfusi dan kongesti, serta pemeriksaan penunjang seperti EKG, foto toraks, ekokardiografi, dan biomarker BNP, NT-proBNP, hs-cTnT, biomarker multipel, miRNA, dan USG paru.

Tatalaksana terkini GJA dilakukan untuk memperbaiki retensi cairan dan penurunan curah jantung lewat terapi farmakologis dan non-farmakologis. Terapi farmakologis seperti diuretik, penyekat EKA, inotropik, vasodilator, tolvaptan, dan serelaksin sedangkan terapi non-farmakologis berupa ultrafiltrasi, LVAD, ICD, dan NMES.

Penelitian menggunakan studi observasional perlu dilakukan untuk menilai faktor lain yang mungkin berperan dalam proses diagnosis dan tatalaksana GJA. Selain itu, perlu dipertimbangkan tatalaksana farmakologis dan non-farmakologis pada fase awal pasien dirawat inap beserta efek samping yang dapat ditimbulkan.

\section{Konflik Kepentingan}

Penulis menyatakan tidak terdapat konflik kepentingan dalam studi ini.

\section{DAFTAR PUSTAKA}

1. Savarese G, Lund LH. Global Public Health Burden of Heart Failure. Card Fail Rev. 2017;03(01):7.

2. Tubaro M, Vranckx P, Price S. Acute heart failure: Epidemiology, classification, and pathophysiology [Internet]. 2015. 1-21 p. Available from: http://www. oxford medicine.com/view/10.1093 /med/9780199687039.001.0001/med9780199687039

3. Reyes EB, Ha J, Firdaus I, Mohd A, Phrommintikul A, Sim D, et al. Heart failure across Asia: Same healthcare burden but differences in organization of care. 
Int J Cardiol [Internet]. 2016;223:163-7. Available from: http://dx.doi.org/10. 1016/ j.ijcard.2016.07.256

4. Lam CSP. Heart failure in Southeast Asia : facts and numbers. ESC Heart Failure. 2015; 2:46-9.

5. Kementerian Kesehatan RI Badan Penelitian dan Pengembangan. Hasil Utama Riset Kesehatan Dasar. Kementrian Kesehat Republik Indones [Internet]. 2018;1100. Available from: http://www. depkes.go.id/resources/download/infoterkini/hasil-riskesdas-2018.pdf

6. Ponikowski P, Voors AA, Anker SD, Bueno H, Cleland JGF, Coats AJS, et al. 2016 ESC Guidelines for the diagnosis and treatment of acute and chronic heart failure. Eur Heart J. 2016;37(27):2129. 200.

7. Rampengan SH. Kapita Selekta: Kardiologi. Rampengan NH, editor. Jakarta: Badan Penerbit FKUI; 2018. 609 p.

8. Manurung DM. Gagal jantung akut. In: Setiati, Siti; Simadibrata, K. Marcellus; Alwi, Idrus; Setiyohadi, Bambang; Sudoyo AW, editor. Ilmu Penyakit Dalam. Keenam. Jakarta: InternaPublishing; 2017. p. 1425.

9. Zipes DP, Libby P, Bonow RO, Mann DL, Tomaselli GF, Braunwald E. Braunwald's Heart Disease: A Textbook of Cardiovascular Medicine Vol. 91 (11th ed). Philadelphia: Elsevier, 2019; 399404.

10. Walsh, R; Fuster, Valentín, Fang JC. Hurst's the Heart Manual of Cardiology. 13th ed. Walsh RA, Fang JC, Fuster V, editors. Ohio: McGraw Hill Professional, 2012: p. 656.

11. Yancy CW, Jessup M, Bozkurt B, Butler J, Casey DE, Colvin MM, et al. 2017 ACC/AHA/HFSA Focused Update of the 2013 ACCF/AHA Guideline for the Management of Heart Failure: A Report of the American College of Cardiology/ American Heart Association Task Force on Clinical Practice Guidelines and the Heart Failure Society of America. Circulation [Internet]. 2017 Aug 8;136(6):e137-61. Available from: https://www.ahajournals.org/doi/10.116 1/CIR.0000000000000509

12. Manurung DM. Gagal jantung akut. In: Setiati S, Simadibrata MK, Idrus A, Setiyohadi B, Sudoyo AW, editors. Ilmu Penyakit
Dalam Keenam. Jakarta: InternaPublishing, 2017; p. 1138-49.

13. Lilly LS. Pathophysiology of heart disease: A collaborative project of medical students and faculty( 6th ed). Taylor C, editor. Boston, Massachusetts: Lippincott Williams \& Wlkins, 2015; 461 p.

14. Perhimpunan Dokter Spesialis Kardiovaskular Indonesia. Pedoman Tatalaksana Gagal Jantung. Pertama. 2015.

15. Marzali A. Menulis Kajian Literatur. Etnosia J Etnogr Indones. 2017;1(2):27.

16. Pivetta E, Goffi A, Nazerian P, Castagno D, Tozzetti C, Tizzani P, et al. Lung ultrasound integrated with clinical assessment for the diagnosis of acute decompensated heart failure in the emergency department: a randomized controlled trial. Eur J Heart Fail. 2019;21(6):754-66.

17. Felker GM, Mentz RJ, Teerlink JR, Voors AA, Pang PS, Ponikowski P, et al. Serial high sensitivity cardiac troponin $\mathrm{T}$ measurement in acute heart failure: Insights from the RELAX-AHF study. Eur J Heart Fail. 2015;17(12):1262-70.

18. Demissei BG, Valente MAE, Cleland JG, O’Connor CM, Metra M, Ponikowski P, et al. Optimizing clinical use of biomarkers in high-risk acute heart failure patients. Eur J Heart Fail. 2016; 18(3):269-80.

19. Vegter EL, Schmitter D, Hagemeijer Y, Ovchinnikova ES, van der Harst $P$, Teerlink JR, et al. Use of biomarkers to establish potential role and function of circulating microRNAs in acute heart failure. Int J Cardiol. 2016;224:231-9.

20. Shanmugam E, Doss CRMP, George M, Jena A, Rajaram M, Ramaraj B, et al. Effect of tolvaptan on acute heart failure with hyponatremia - A randomized, double blind, controlled clinical trial. Indian Heart J [Internet]. 2016;68:S15-21. Available from: http://dx.doi.org/10. 1016/j.ihj.2015.07.006

21. Konstam MA, Kiernan M, Chandler A, Dhingra R, Mody FV, Eisen H, et al. Short-term effects of tolvaptan in patients with acute heart failure and volume overload. J Am Coll Cardiol. 2017;69(11):1409-19.

22. Metra M, Teerlink JR, Cotter G, Davison BA, Felker GM, Filippatos G, et al. Effects of serelaxin in patients with acute heart 
failure. N Engl J Med. 2019;381(8): 716-26.

23. Maggioni AP, López-Sendón J, Nielsen OW, Hallén J, Aalamian-Mattheis M, Wang $\mathrm{Y}$, et al. Efficacy and safety of serelaxin when added to standard of care in patients with acute heart failure: results from a PROBE study, RELAX-AHF-EU. Eur J Heart Fail. 2019;21(3):322-33.

24. Kondo T, Yamada S, Tanimura D, Kazama S, Ishihara T, Shimojo M, et al. Neuromuscular electrical stimulation is feasible in patients with acute heart failure. ESC Heart Fail. 2019;6(5):975-82.

25. Gheorghiade M, Konstam M a, Burnett JC, Grinfeld L, Maggioni AP, Swedberg K, et al. an Oral vasopressin antagonist , in patients hospitalized for heart failure. Jama. 2007;297(12):1332-43.

26. Patra S, Sadananda K, Santhosh K, Rajith K, Manjunath C, Basappa $\mathrm{H}$, et al. Short term efficacy and safety of low dose tolvaptan in patients with acute decompensated heart failure with hyponatremia: a prospective observational pilot study from a single center in South India. Heart Views. 2014;15(1):1.
27. Matsuzaki M, Hori M, Izumi T, Fukunami M. Efficacy and safety of tolvaptan in heart failure patients with volume overload despite the standard treatment with conventional diuretics: a phase iii, randomized, double-blind, placebocontrolled study (QUEST Study). Cardiovasc Drugs Ther [Internet]. 2011;25(S1):33-45. Available from: http://link.springer.com/10.1007/s1055 7-011-6304-x

28. Matsue Y, Maaten JM, Suzuki M, Torii S, Yamaguchi S, Fukamizu S, et al. Early treatment with tolvaptan improves diuretic response in acute heart failure with renal dysfunction. Clin Res Cardiol. 2017;106(10):802-2.

29. Teerlink JR, Cotter G, Davison BA, Felker GM, Filippatos G, Greenberg BH, et al. Serelaxin, recombinant human relaxin-2, for treatment of acute heart failure (RELAX-AHF): A randomised placebocontrolled trial. Lancet [Internet]. 2013;381(9860):29-39. Available from: http://dx.doi.org/10.1016/S01406736(12)61855-8 